\title{
Influence of Raw Materials Rich in Proteins on the Quality of Gluten-Free Noodles
}

\author{
Silvana Beatriz Sabbatini, Hugo Diego Sánchez ${ }^{*}$, María Adela de la Torre, Carlos Alberto Osella
}

Instituto de Tecnología de Alimentos, Facultad de Ingeniería Química-Universidad Nacional del Litoral, Santa Fe, Argentina

\section{Email address:}

hsanchez@fiq.unl.edu.ar (H. D. Sánchez)

\section{To cite this article:}

Silvana Beatriz Sabbatini, Hugo Diego Sánchez, María Adela de la Torre, Carlos Alberto Osella. Influence of Raw Materials Rich in Proteins on the Quality of Gluten-Free Noodles. International Journal of Nutrition and Food Sciences. Vol. 4, No. 2, 2015, pp. 169-172.

doi: $10.11648 /$ j.ijnfs.20150402.17

\begin{abstract}
The objective of this work was to develop a premix, fortified in the protein content, allowing the making of gluten-free noodles incorporating raw materials rich in proteins and which permit an adequate physical and sensory property. Soy flour, defatted soy flour, low fat soy flour and whey protein concentrate were used as rich protein ingredients. The following aspects were analyzed: moisture of not cooked noodles, water absorption of cooked noodles, loss of solids by cooking, and some sensorial characteristics as taste, colour and texture. According to the obtained results we have selected low fat soy flour as the flour that provides the best technological response having a minor loss of solids by cooking and a more favourable sensory evaluation.
\end{abstract}

Keywords: Noodles, Rich Protein Ingredients, Premix For Celiac

\section{Introduction}

The use of vegetable proteins has been applied for a long time and has spread worldwide. These proteins are mainly from soybean because their nutritional characteristics make it to be a good addition to cereal-based diets. They may be used as flours, concentrates, isolated and textured; remain fit to meet only if they have been processed correctly for human requirements. The great advantage caused by products made from the use of composite flours is that they are made from cereals deficient in the amino acid lysine and using a raw material rich in lysine increases the biological value of such proteins [1]. The most common ingredients used to prepare gluten-free products are corn starch, potato starch, tapioca starch and rice flour. Some researchers have also conducted studies on the development of nutritionally enriched and sensorially acceptable noodles jointly using the defatted corn germ meal, soybean meal and cassava starch to replace the wheat semolina durum [2]. The use of a protein in combination with a polysaccharide is well known by the researchers, but the new concept is to alter the protein structure at nanoscale [3]. The elaboration of gluten-free noodles using sweet potato flour fortified with soy flour and soy protein isolate in different proportions, allowed to obtain variations in both the strength and cohesiveness, but very acceptable products were obtained in all cases [4]. The fact that Argentina is one of the largest producers of soybeans in the world and considering that the waste from oil soybean industry are of high volume, support the conclusion that there are alternatives to use this raw material in the production of other improved foods from the point of view of the protein quantity and quality [5]. Whereas foods of social interest are intended to have high nutritional value products that can be used in the preparation of traditional dishes without having to create new eating habits, these products based in soy bean can satisfy this requirement [1]. On the other hand, researchers have intensified investigations concerning the use of whey protein concentrate (WPC) in noodles such as macaroni type. The enriched product has a high nutritional value because of the presence of lysine, methionine and tryptophan in the WPC used as raw material. Also is considered a good supplement because it suffers minimal changes during noodle making, including the cooking stage $[6,7]$. This whey protein concentrate (WPC) is a by-product of the cheese making process in which the insoluble proteins that form the principal product are separated of the soluble whey proteins. This whey and through techniques such as ultrafiltration becomes protein concentrate, which is used by different food industries [8]. The functional properties of different raw materials rich in proteins are innumerable. They are its emulsifying capacity, the possible replacement of fat 
in diet products, its high solubility, its aeration power, its potential in the development of colour and flavour, its binding action with water, among others [9].

The aim of this work was to develop a premix, fortified in the protein content, allowing the making of gluten-free noodles incorporating raw materials rich in proteins and which permit an adequate physical and sensory property.

\section{Material and Methods}

\subsection{Materials}

ALDEMAN cassava starch $[13.5 \%$ moisture, $0.10 \%$ protein $(\% \mathrm{~N} \times 6.25), 55-63{ }^{\circ} \mathrm{C}$ gelatinization temperature] was from Cooperativa Agrícola Industrial San Alberto Ltda., Misiones, Argentina. TRIMACER rice flour [13.5\% moisture $6.2 \%$ protein $(\% \quad \mathrm{~N} \times 6.25), 65-72{ }^{\circ} \mathrm{C}$ gelatinization temperature] was a product of Atilio Betella y Cía, Santa Fe, Argentina. Pregelatinized cornstarch GLUTAGEL "NT", [8\% moisture; $0.2 \%$ protein $(\mathrm{N} \times 5.7)$; Brookfield viscosity coldgel at a concentration of $8 \%$ and $100 \mathrm{rpm}$ : $800-1600 \mathrm{cp}$ ] was from Glutal SA, Esperanza, Argentina. Guar gum (1\% viscosity $3000 \mathrm{cp}$ ) was from Chemistry Oeste, Buenos Aires, Argentina. Egg powder (3\% moisture; $43 \%$ protein) provided by Poultry Company Inc., Santa Fe, Argentina. Soy Flour (SF) [14.0\% moisture, $23.1 \%$ protein $(\% \mathrm{~N} \times 6.25), 18 \%$ fat]; Defatted Soy Flour (DSF) $[7.5 \%$ moisture, $40.5 \%$ protein $(\%$ $\mathrm{N} \times 6.25), 3.0 \%$ fat]; and Low Fat Soy Flour (LFSF) [7.2\% moisture, $44 \%$ protein ( $\% \mathrm{~N}$ x 6.25), 8\% fat] from América Pampa Agroindustrial S. A., Buenos Aires, Argentina. Whey Proteins Concentrate (WPC) [3.2\% moisture, 35\% protein ( $\%$ $\mathrm{N}$ x 6.38), 3.5\% fat, 51.3\% lactose] provided by Milkaut S.A., Santa Fe, Argentina. The four raw materials rich in proteins (SF, DSF, LFSF and WPC) were tested at levels of $0,5,10$ and $15 \%$.

Equipment used included an Oster mixer with two stainless steel whisks at $400 \mathrm{rpm}$. The apparatus used to laminate and cut the dough was Top House Model QF 150.

\subsection{Noodle Manufacture}

Noodles were manufactured according to the formulation selected by Sabbatini et al. [10] and shown in Table 1. Raw materials rich in proteins were used as variables.

Table 1. Formulation for gluten free noodle using raw materials rich in proteins

\begin{tabular}{lll}
\hline Raw material & Quantity (g) & Proportion \\
\hline Cassava starch & 97.5 \\
Rice flour & $\begin{array}{l}30.5 \\
\text { Pregelatinized cornstarch }\end{array}$ & $\begin{array}{l} \\
\text { W.5 }\end{array}$ \\
WPC & variable & \\
Soy Flour (SF) & variable & variable \\
Defatted Soy Flour (DSF) & variable & variable \\
Low Fat Soy Flour (LFSF) & variable & variable \\
Egg powder & 22.5 & 15 \\
Guar gum & 3.0 & 2 \\
Salt & 3.0 & 2 \\
Water & 78 & 52 \\
\hline
\end{tabular}

Powder ingredients (corn starch, rice flour, cassava starch, raw material rich in protein, guar gum, egg powder and salt, were mixed at $400 \mathrm{rpm}$ for $1 \mathrm{~min}$. Water was added and then two minutes of mixing until achieve the formation of pellets. Then the dough was laminated gradually decreasing the spacing of the rollers, from the position $1(4 \mathrm{~mm})$ to the position $7(1.5 \mathrm{~mm})$. Once the dough was sheeted to a thickness of $1.5 \mathrm{~mm}$ was cut into wide strips using the same Top House laminator with the appropriate fixture for cutting and so obtains the noodles.

\subsection{Noodle Evaluation}

\subsubsection{Moisture of Not Cooked Noodles}

It is determined at $105^{\circ} \mathrm{C}$ for 24 hours, weighing 3-5 grams of sample. The determinations were performed in triplicate and the moisture values emerged using the following equation:

Moisture $(\%)=[($ weight of wet noodle - weight of dry noodle)/weight of wet noodle] x 100 .

\subsubsection{Water Absorption of Cooked Noodles}

Water absorption emerged using the method by measuring the moisture on samples of noodles cooked during five minutes. It was determined at $105^{\circ} \mathrm{C}$ for 24 hours on $3-5$ grams of sample. Water absorption values were obtained by triplicate and using the following equation:

\section{Water absorption $=$ moisture of cooked sample $/(100$ - moisture of cooked sample).}

\subsubsection{Loss of Solids by Cooking}

For each test $15 \mathrm{~g}$ of noodles, of approximately $10 \mathrm{~cm}$ long, were introduced into a container with $150 \mathrm{ml}$ boiling water. After the time selected, the sample was drained and washed three times with $10 \mathrm{ml}$ of water at $20^{\circ} \mathrm{C}$. This washing water was added to the water cooking. An aliquot of $25 \mathrm{ml}$ was taken from the total volume of water in which the amount of solids was determined by evaporation at $105^{\circ} \mathrm{C}$ during 24 hours. The amount of solids was referred to the original sample according to the following equation:

Loss by cooking $(\%)=($ weight of total solids in the cooking water and washing / dry weight of noodles before cooking) $\mathrm{x}$ 100.

\subsubsection{Sensory Analysis}

Noodles obtained in experimental tests were subjected to scoring to determine their sensory characteristics on a comparative basis. Experts in a number of four scored the individual characteristics of the noodles which were related to those of a hypothetical standard noodle. Each sample was served at the same time after they were cooked. Experts scored each sample once and assigned scores on a scale of 110 for texture (firmness, chewiness and stickiness), colour and taste. The scale of values established was: Excellent (910), Very Good (8-9), Good (7-8), Regular (6-7), Fair (5-6), Very Poor (4-5) and Unacceptable (1-4). 


\subsection{Statistical Analysis}

Analysis of variance (ANOVA) was performed and the mean values of triplicates were compared to establish significant differences according to the method of Duncan's Multiple Range [11].

\section{Results and Discussion}

\subsection{Moisture of Not Cooked Noodles}

Table 2 shows the results of moisture values obtained with the gluten free noodles, made with raw materials rich in proteins, showing that increasing the level of WPC, produces a decrease in the moisture content. This happens as a consequence that an increasing of the amount of WPC in the formulation makes necessary to decrease progressively adding water to make smooth dough. This addition of water, if excessive, produces greater plasticity and a loss of technological quality [12].

Table 2. Moisture of gluten free noodles made with raw materials rich in proteins

\begin{tabular}{lllll}
\hline \multirow{2}{*}{ Level (\%) } & \multicolumn{4}{l}{ Moisture (\%) } \\
\cline { 2 - 5 } & WPC & SF & DSF & LFSF \\
\hline 0 & $37.4 \mathrm{ab}$ & $37.4 \mathrm{ab}$ & $37.4 \mathrm{ab}$ & $37.4 \mathrm{ab}$ \\
5 & $35.5 \mathrm{~d}$ & $37.1 \mathrm{bc}$ & $37.4 \mathrm{ab}$ & $37.6 \mathrm{a}$ \\
10 & $33.9 \mathrm{e}$ & $36.9 \mathrm{bc}$ & $37.6 \mathrm{a}$ & $37.8 \mathrm{a}$ \\
15 & $33.5 \mathrm{e}$ & $36.7 \mathrm{c}$ & $37.1 \mathrm{bc}$ & $37.9 \mathrm{a}$ \\
\hline
\end{tabular}

WPC: Whey protein concentrate. SF: Soy flour. DSF: Defatted soy flour. LFSF: Low fat soy flour Different letters indicate significant differences $(\mathrm{p}$ $<0.05)$

Moreover, when the added soy flour is analyzed, it is observed that the moisture content is almost constant when increases the replacement percentage. This occurs despite the fact that with increasing the soy flour content in the formulation we should incorporate an increasing amount of water to achieve good quality noodle, which is different from what happens with the WPC. This agrees with Perez et al. [13], which with the addition of soy protein derivatives in sugar cookie dough does not get final increased dough moisture.

Since the WPC gives plasticity to the dough and the soy flour tends to make it dry and tough, it would be expected that the simultaneous addition of these two ingredients results in a dough with acceptable characteristics. Obviously the proteins of WPC and soy flours do not interact in the same way to do the dough $[8,14]$. Whey proteins have a globular conformation in which the polypeptide chains have a uniform distribution of hydrophobic groups and polar groups at $\mathrm{pH}$ close to seven, which make them spherical shape and fold the inward to the hydrophobic group and outward to the polar group with generating a relatively labile structure that gives high plasticity to the dough [15].

\subsection{Water Absorption of Cooked Noodles}

Table 3 shows the values of water absorption obtained when WPC and three different soybean flours are used as protein-rich ingredients.

Table 3. Water absorption of gluten free noodles made with raw materials rich in proteins

\begin{tabular}{lllll}
\hline \multicolumn{6}{l}{ Water absorption (g of water/g of dry sample) } \\
\hline Level (\%) & WPC & SF & DSF & LFSF \\
\hline 0 & $2.03 \mathrm{~d}$ & $2.03 \mathrm{~d}$ & $2.03 \mathrm{~d}$ & $2.03 \mathrm{~d}$ \\
5 & $1.87 \mathrm{f}$ & $2.08 \mathrm{~d}$ & $2.10 \mathrm{~cd}$ & $2.05 \mathrm{~d}$ \\
10 & $1.94 \mathrm{e}$ & $2.14 \mathrm{~cd}$ & $2.22 \mathrm{~b}$ & $2.13 \mathrm{c}$ \\
15 & $2.13 \mathrm{c}$ & $2.16 \mathrm{c}$ & $2.37 \mathrm{a}$ & $2.25 \mathrm{~b}$ \\
\hline
\end{tabular}

WPC: Whey protein concentrate. SF: Soy flour. DSF: Defatted soy flour. LFSF: Low fat soy flour Different letters indicate significant differences ( $p$ $<0.05)$

Analyzing Table 3 we can see that although at low levels of WPC replacement there is a reducing water absorption compared to the control, when increases this replacement level with WPC also increases the amount of water retained. On the other hand, soy flours have water retention higher than control at low replacement values, thus being always higher than control at higher levels of use. This may be because the soy proteins compete strongly for water with the other proteins present in the formulation, which coincides with some stipulations [16], who pointed out that soy proteins have a high hydrophilicity, competing for the water not only with the proteins present in the formulation, but also with starch.

\subsection{Loss of Solids by Cooking}

In Table 4 it can be seen that for all analyzed raw materials there is an increase in the loss of solids by cooking when increases the percentage replacement, either at zero time as cooking time of 5 minutes, this latter one is for when the noodles are cooked "al dente".

Table 4. Loss of solids, at 0 and 5 minutes cooking, of gluten free noodles made with raw materials rich in proteins

\begin{tabular}{|c|c|c|c|c|c|c|c|c|}
\hline \multicolumn{9}{|c|}{ Loss of solids by cooking (\%) } \\
\hline \multirow{2}{*}{ Level (\%) } & \multicolumn{2}{|l|}{ WPC } & \multicolumn{2}{|l|}{$\mathbf{S F}$} & \multicolumn{2}{|l|}{ DSF } & \multicolumn{2}{|l|}{ LFSF } \\
\hline & 0 min & 5 min & 0 min & $5 \mathrm{~min}$ & $0 \mathrm{~min}$ & $5 \mathrm{~min}$ & $0 \mathrm{~min}$ & $5 \min$ \\
\hline 0 & $0.86 \mathrm{f}$ & $6.10 \mathrm{~h}$ & $0.86 \mathrm{f}$ & $6.10 \mathrm{~h}$ & $0.86 \mathrm{f}$ & $6.10 \mathrm{~h}$ & $0.86 \mathrm{f}$ & $6.10 \mathrm{~h}$ \\
\hline 5 & $1.26 \mathrm{~cd}$ & $7.70 \mathrm{e}$ & $1.39 \mathrm{c}$ & $8.31 \mathrm{~d}$ & $1.23 \mathrm{~d}$ & $7.06 \mathrm{fg}$ & $1.08 \mathrm{e}$ & $5.06 \mathrm{j}$ \\
\hline 10 & $1.57 \mathrm{~b}$ & $8.48 \mathrm{~d}$ & $1.64 \mathrm{~b}$ & $9.18 \mathrm{~b}$ & $1.22 \mathrm{~d}$ & $8.09 \mathrm{~d}$ & $1.27 \mathrm{~d}$ & $5.52 \mathrm{i}$ \\
\hline 15 & $1.97 \mathrm{a}$ & $8.66 \mathrm{c}$ & $1.61 \mathrm{~b}$ & $10.10 \mathrm{a}$ & $1.52 \mathrm{~b}$ & $8.89 \mathrm{bc}$ & $1.11 \mathrm{e}$ & $6.72 \mathrm{~g}$ \\
\hline
\end{tabular}

WPC: Whey protein concentrate. SF: Soy flour. DSF: Defatted soy flour. LFSF: Low fat soy flour Different letters indicate significant differences for 0 and 5 minutes separately $(p<0.05)$ 
The cooking time is especially important because it affects the texture and flavour of pasta. So if pasta is cooked less than indicated, the texture will be hard and a flour flavour highlighted; if instead noodles are overcooked, they become whitish, easily broken into small pieces and have soft and sticky texture, which is regarded by consumers as an unpleasant mouth feel [17].

Comparing the behaviour of SF, DSF and LFSF, is more convenient to use the latter because for the same percentage added to the formulation, the cooking loss is much lower.

\subsection{Sensory Analysis}

Table 5 shows the results of sensory evaluation of noodles made with WPC and the different types of soy flour, at a substitution level of $15 \%$.

Table 5. Sensory analysis of gluten free noodles made with $15 \%$ of raw materials rich in proteins

\begin{tabular}{lllll}
\hline Score & & & & \\
\hline Attributes & WPC & SF & DSF & LFSF \\
\hline Taste & $4.8 \mathrm{c}$ & $5.1 \mathrm{bc}$ & $5.9 \mathrm{~b}$ & $8.0 \mathrm{a}$ \\
Colour & $7.0 \mathrm{~b}$ & $6.2 \mathrm{c}$ & $7.5 \mathrm{~b}$ & $9.3 \mathrm{a}$ \\
Texture & $6.8 \mathrm{c}$ & $7.8 \mathrm{~b}$ & $8.0 \mathrm{~b}$ & $9.7 \mathrm{a}$ \\
\hline
\end{tabular}

WPC: Whey protein concentrate. SF: Soy flour. DSF: Defatted soy flour. LFSF: Low fat soy flour Different letters indicate, for each attribute, significant differences $(\mathrm{p}<0.05)$

In noodles added with the low fat soy flour (LFSF) we found a better assessment on the attributes of flavour, colour and texture compared with the WPC and with the other soy flours used.

\section{Conclusions}

Based on the results obtained from this study, we have selected the low fat soy flour (LFSF) as the flour that provides the best technological responses having a minor loss of solids by cooking and a more favourable sensory evaluation. We have determined a better assessment in all sensory attributes.

\section{References}

[1] Orbea, M.M. and Apro, N.J. (2004). Desarrollo de alimentos de alto valor nutricional y bajo costo en base a soja. INTI Cereales y Oleaginosas. $5^{\circ}$ Jornadas de Desarrollo e Innovación. http://www4.inti.gov.ar/GD/5jornadas/doc/56.doc

[2] Granito, M., Torres, A. and Guerra, M. (2003). Desarrollo y evaluación de una pasta a base de trigo, maíz, yuca y frijol. Interciencia. 28:372-379.

[3] Boswell, S., Mc.Donough, C.M. and Rooney, L.W. (2009). Gelatin as a functional ingredient in gluten-free bread. $A A C C$ International Annual Meeting. Maryland, USA.
[4] Limroongreungrat, K. and Huang, Y.W. (2007). Pasta products made from sweetpotato fortified with soy protein. LWT-Food Science and Technology. 40:200-206.

[5] Genta, M.L. and Álvarez, N. (2006). El Complejo Soja. Facultad de Ciencias Exactas y Tecnología-Universidad Nacional de Tucumán. http://www.herrera.unt.edu.ar/revistacet/anteriores/.../N28Ext. 01.pdf

[6] Sienkiewicz, T. and Riedel, C.L. (1990). Utilization of Whey. Chap 4, p.215 of Whey and Whey Utilization. Verlag Th. Mann. Gelsenkirchen-Buer. $2^{\circ}$ ed. Germany.

[7] Jacobson, K.A. (1997). Whey protein concentrates as functional ingredients in baked goods. Cereal Foods World. 42:138-141

[8] Visentín, A.N., Drago, S.R., Osella, C.A., de la Torre, M.A., Sánchez, H.D. and González, R.J. (2009). Efecto de la adición de harina de soja y concentrado proteico de suero de queso sobre la calidad del pan y la dializabilidad de los minerales. Archivos Latinoamericanos de Nutrición. 59:325-331.

[9] Schaller, A. (2008). Sueros de lechería. Cadenas Alimentarias. Dirección de Industrias Alimentarias y Agroindustrias. Ministerio de la Producción. Presidencia de la Nación. http://www.alimentosargentinos.gov.ar/0-3/r_44/cadenas/ Lacteos.html

[10] Sabbatini, S., de la Torre, M., Sánchez, H., Osella, C. (2014). Design of a premix for making gluten free noodles. International Journal of Nutrition and Food Sciences. 3:488492.

[11] Montgomery, D. C. (1991). Métodos y Diseños de Superficie de Respuesta. Pág. 467-485, en: Diseño y Análisis de Experimentos. Grupo Editorial Iberoamericana. México.

[12] Sánchez, H. D. , Osella, C.A., de la Torre , M.A., Mancuello, J.C., Fabre, H.C. Barrio, M.C. and Renner. E. (1990). Whey protein concentrate in baking. Effect on rheological properties. In: Protein fortification of cereal food products with whey protein concentrates. Ed. Renner. Giessen, Germany.

[13] Pérez, S.R., Osella, C.A., de la Torre, M.A. and Sánchez, H.D. (2008). Efecto del mejoramiento proteico sobre los parámetros de calidad nutricional y sensorial de galletitas dulces (cookies). Archivos Latinoamericanos de Nutrición. 58:403-410.

[14] Sánchez, H.D., Osella, C.A. and de la Torre, M.A. (1998). Mejoramiento de la calidad nutricional de pan tipo francés. Archivos Latinoamericanos de Nutrición. 48:349-353.

[15] Giménez, J.M. (2008). Leche y productos lácteos. $\mathrm{http}: / / w w w . m o n o g r a f i a s . c o m / t r a b a j o s 64 /$ leche-productoslacteos/leche-productos-lacteos.shtlm

[16] Ryan K.J. and Brewer M.J. (2007). In situ examination of starch granule soy protein and wheat protein interactions. Food Chemistry. 104:316-629.

[17] Granito, M. and Ascanio, V. (2009). Desarrollo transferencia tecnológica de pastas funcionales extendidas con leguminosas. Archivos Latinoamericanos de Nutrición. 59:71-77. 